\title{
artículos
}

\section{¿De forma defectuosa y gusto depravado? un pro- yecto inédito de José Martín de Aldehuela para el tabernáculo de la Catedral de Málaga (1796)'}

\author{
Rosario Camacho Martínez y Juan Antonio Sánchez López \\ Universidad de Málaga
}

RESUMEN

Este trabajo presenta un diseño de tabernáculo para la Capilla Mayor de la Catedral de Málaga, firmado por el arquitecto José Martín de Aldehuela, que responde a las formas del barroco clasicista de influencia italiana y del rococó. Partiendo de un análisis del pensamiento teológico y de la liturgia sacramental, el estudio se integra en la concepción de este templete como edificio ideal, situándolo en el contexto del complejo y secular proceso constructivo de este elemento arquitectónico para la basílica malagueña.

PALABRAS CLAVE: Barroco clasicista/ Rococó/ Arquitectura/ Catedral/ Málaga/ Tabernáculo/ Eucaristía/ Iconología/ Utopía/ José Martín de Aldehuela.

\section{Of defective form and depraved taste? Jose Martin de Aldehuela's unpublis- hed project for the tabernacle of the Málaga's Cathedral (1796) \\ ABSTRACT}

This article studies made a drawing for the tabernacle of the High Altar in Cathedral of Málaga (Spain) designed by José Martín de Aldehuela, whose stylistic language corresponds to Classicist Baroque influenced since Italy and Rococo. Theological thinking and Eucharistc Liturgy explain tabernacle's conception such an ideal buiding in the specific context of its construction for the Cathedral of Málaga.

KEY wORDS: Classicist Baroque/ Rococo/ Architecture/ Cathedral/ Málaga/ Tabernacle/ Iconology/ Utopia/ José Martín de Aldehuela.

Desde tiempos pretéritos, la concepción del tabernáculo o templete del altar mayor como edificio ideal se identificó con la utopía de la planta centralizada, que tanta fascinación ejerció sobre generaciones de arquitectos a partir del Renacimiento. Al ejercicio arquitectónico se sumaban las connotaciones semánticas que relacionaban semejantes 'templos en miniatura' con objetos y/o construcciones tan carismáticas como el Arca de la Alianza y el Templo de Salomón. Por ende, el símil veterotestamentario propiciaba una ocasión única para profundizar en el continuismo, sin fisuras, entre la Vieja y la Nueva Ley y, de modo paralelo, ahondar en las

* CAMACHO MARTÍNEZ, Rosario y SÁNCHEZ LÓPEZ, Juan Antonio: “¿De forma defectuosa y gusto depravado? un proyecto inédito de José Martín de Aldehuela para el tabernáculo de la Catedral de Málaga (1796)", en Boletín de Arte, $\mathrm{n}^{\circ}$ 30-31, Departamento de Historia del Arte, Universidad de Málaga, 2009-2010, págs. 147-168. Fecha de recepción: Junio de 2009.

1 Este trabajo se integra en una investigación más amplia dentro del Proyecto I+D+I HAR 2009-12095 "Tradición e innovación. La recepción de los modelos italianos en la periferia mediterránea y su difusión: Andalucía durante la Edad Moderna", Investigadora Principal: Rosario Camacho Martínez. 
posibilidades sincréticas del pensamiento cristiano respecto a la filosofía del mundo antiguo, auspiciadas por las corrientes humanistas.

No sorprende, pues, que todo ello fuese gestando entre los sectores más cultos de la comitencia eclesiástica una auténtica conciencia utópica que, en gran medida, quedó plasmada en el tortuoso proceso constructivo de tabernáculo de la Catedral de Málaga, iniciado en el Quinientos y precipitadamente culminado en el XIX. A lo largo de esos siglos, quedaría en evidencia la conciencia utópica del Cabildo promotor y sus indecisiones estéticas, a la hora de rematar la Capilla Mayor del templo con el hito sacramental que debía representar, por su suprema perfección, la morada terrena de la Divinidad.

José Martín de Aldehuela fue uno de los muchos y notables nombres implicados en tan compleja controversia. La aparición en una colección particular malagueña de su proyecto de 1796 para el tabernáculo malagueño -conocido documentalmente, pero no visualmente hasta ahora-, nos brinda la oportunidad de retornar a esta cuestión, en comunión con el estudio exhaustivo y análisis estilístico de tan sugestivo diseño.

\section{EUCARISTIA Y DOCTRINA.}

A nadie escapa que la antigüedad de la Eucaristía es similar a la del Cristianismo. Sin embargo, desde su institución por Jesucristo en la Última Cena a su exaltación pública y solemne por la liturgia y la paraliturgia de la Iglesia pasaron, al menos, diez siglos ${ }^{2}$. Sin que nunca dejase de ser el epicentro y el corazón de la vivencia espiritual y mistérica de los creyentes, en los primeros tiempos el Sacramento solía reservarse en píxides en forma de paloma suspendidas sobre el altar, o bien en pequeñas cajas depositadas en lugares recónditos del templo, similares a sacristías, e incluso en casas particulares ${ }^{3}$. Con todo, desde el siglo VIII se intuye un progresivo interés por magnificar la presencia 'visible' del Sacramento. De esta manera, a principios del $X$ se tienen noticias de la costumbre de encender una lámpara permanente ante el mismo, que comienza a generalizarse en el XII ${ }^{4}$. En esta misma centuria, también comienzan a prodigarse los ciboria o pequeños tabernáculos detrás del altar que, al llegar el XVI, se convertirán en piezas arquitectónicas monumentales capaces de reflejar la idea de la residencia terrena de Cristo, mediante la imagen del edificio perfecto y su asimilación simbólica al Arca de la Alianza del Antiguo Testamento.

En este contexto, cabe atribuir indirectamente a las corrientes heterodoxas y

2 FERNÁNDEZ JUÁREZ, G. y MARTíNEZ GIL, F. (coords.): La fiesta del Corpus Christi. Cuenca, Ediciones de la Universidad de Castilla-La Mancha (UCLM), 2002.

3 GONZÁLEZ TORRES, J.: Emblemata Eucarística. Símbolos animados de la iconografía cristológica y sacramental. Málaga, Universidad, 2009, págs. 190-191.

4 GARCÍA VILLOSLADA (S.I.), R.: Historia de la Iglesia Católica, t. II: Edad Media (800-1303). La cristiandad en el mundo europeo y medieval. Madrid, BAC, 1953, pág. 942. 
heréticas, el estímulo que terminaría convirtiendo la fiesta eucarística en el gran día de los países católicos. El escepticismo, las dudas y las críticas que suscitaba la creencia en la presencia real de Cristo en la Sagrada Forma hizo encender entre los fieles un fervor intensísimo, al que la propia Iglesia supo dar respuesta mediante una serie de disposiciones ceremoniales y litúrgicas, primero; y un refrendo dogmático después. De esta manera, el IV Concilio de Letrán dispuso, en 1215, que todos los fieles recibiesen la comunión siquiera una vez al año, además de introducir en el canon de la celebración el rito de la elevación de la hostia y el cáliz después de la consagración. Al mismo tiempo, se estableció hacer sonar la campanilla en este momento, con el fin de que el pueblo se prosternase en señal de adoración al Sacramento, obligación ratificada más tarde por Gregorio $X^{5}$.

A propósito de la cuestión, no puede minusvalorarse el titánico esfuerzo teológico del Catolicismo a la hora de construir una superestructura dogmática, literaria y legislativa en torno a una devoción abstracta, únicamente justificada y justificable por la Fe que permite 'ver' con los ojos del alma lo que niegan ver los ojos del cuerpo. En el crepúsculo de la Edad Media, Santo Tomás de Aquino y San Buenaventura habían iniciado esa ardua tarea, felizmente rematada por el Concilio de Trento al establecer categóricamente el blindaje dogmático del misterio de la Eucaristía. En concreto, las Sesiones XIII (1551) y XXI (1562) del Sínodo Tridentino definieron con una clarividencia y precisión teológica sin precedentes la controvertida doctrina de la Transubstanciación, cerrando filas en torno a la taxativa afirmación de que en las especies consagradas del pan y del vino están y permanecen el cuerpo, la sangre, el alma y la divinidad de Jesucristo. Junto a este tema, el Concilio cerraba filas en torno a los cinco puntos sobre la Comunión y el anatema lanzado con férrea contundencia sobre los detractores 6 .

Conscientes de la trascendencia de estas tesis, las tipologías creadas para la configuración material de los objetos y vasos sagrados y, por extensión, de los propios 'contenedores' y expositores sacramentales fueron ganando, sobre todo a partir del Quinientos, en complejidad estética, en belleza y perfección de diseño, a la par que iban diversificándose y especializándose acorde a las exigencias de la liturgia que imponía el uso de receptáculos adecuados para la reserva, preservación y/o exposición pública y solemne del pan eucarístico.

Ya desde los tiempos medievales, el culto sacramental y el aludido desarrollo de la teología eucarística fueron exigiendo gradualmente nuevos esfuerzos arquitectónicos y artísticos que permitiesen 'habilitar' en el templo un habitáculo específico cuya misión no era otra que la de cumplir con rotunda dignidad el referido papel de morada terrena y efectiva de la divinidad entre los hombres, inferido del misterio de la presencia real de Cristo en la Eucaristía. Sin embargo, no puede olvidarse

\footnotetext{
5 Ibídem, págs. 936-937.

6 LÓPEZ DE AYALA, I.: El Sacrosanto y Ecuménico Concilio de Trento, traducido al idioma castellano por... agrégase el texto latino corregido según la edición auténtica de Roma publicada en 1564. Burgo de Osma, Imprenta de José Redondo Calleja, 1856, págs. 90-100 y 162-167.
} 
cómo las premisas formales y semánticas que fueron dando cuerpo al Sancta Sanctorum del templo cristiano hunden sus raíces en la Antigüedad. Para ser más exactos, cuando, por influjo romano, los cristianos transfirieron los emblemas del honor y la gloria a la figura de Cristo y los mártires, sumando a las connotaciones áulicas y celestiales del dosel o baldaquino un simbolismo de naturaleza memorial y mortuoria que, en última instancia, terminaría asociando al tabernáculo del altar, el carácter de hito destinado a señalar el 'emplazamiento' exacto de la permanente teofanía implícita por la presencia del Sacramento en su interior.

Desde esta perspectiva, la configuración arquitectónica y trasfondo conceptual del tabernáculo permitía entenderlo como un edificio necesariamente perfecto, por asimilarse a la imago mundi que había de poner en relación lo subterráneo, lo terrestre y lo celeste, vinculándolo al simbolismo que la tradición católica y- por extensión hebrea- adjudicaba a un Dios-Arquitecto que había diseñado 'personalmente' su propia morada: primeramente, en el 'tabernáculo' o tienda que había hecho las veces de 'templo portátil' a lo largo del éxodo israelita por el desierto ${ }^{7} \mathrm{y}$, después en el Templo de Jerusalén construido por Salomón ${ }^{8}$. Tales deseos justifican que, desde los ciboria paleocristianos y medievales, se consolidase una 'estructuratipo' que superpuso a la planta centralizada un organismo cupular ligero, alzado sobre columnas. De esta manera, y al acotarse un espacio interior definido, este tipo de edículos delimita un temenos capaz de engendrar, por y en sí mismo, un espacio interior de polivalentes acepciones connotativas. Más tarde, la fascinación del Renacimiento por el templo de planta centralizada como máxima expresión de la perfección divina, reconoció en la arquitectura de los tabernáculos de altar una vía paralela mediante la cual poder llevar a cabo esa fusión del Cristianismo con el platonismo, tan anhelada por autores como Marsilio Ficino y Lorenzo Valla, para quienes Platón había 'prefigurado' poéticamente al Dios del Evangelio, además de haber definido la inmortalidad del alma?.

\section{HUMANISMO, TEORÍA ARQUITECTÓNICA y PRÁCTICA ARTÍSTICA.}

En el plano de la arquitectura andaluza del Renacimiento, la configuración estructural y simbólica de las capillas mayores de las Catedrales de Málaga y Granada habían consagrado un modelo de santuario en plena sintonía con el espíritu humanista del Quinientos, por lo demás capaz de conciliar -sincréticamente y sin fisuras- el idealismo utópico, filosófico y místico heredado de la tradición medieval y la utopía renaciente con el proselitismo y autoafirmación dogmáticos canalizados desde la apología eucarística postridentina ${ }^{10}$. Sin embargo, la imperiosa necesidad

\footnotetext{
7 Éxodo 26, 1-37.

8 I Libro de los Reyes 6, 1-38.

9 MíGUEZ, J.M.: “Introducción a Platón”, en PLATÓN: Obras completas. Madrid, Aguilar, 1966, págs. 87-88.

10 GONZÁLEZ TORRES, J.: "Iconografía y mensaje en los programas eucarísticos de la arquitectura del Barroco en Málaga". En: COLOMA MARTÍN, I. y J. A. SÁNCHEZ LÓPEZ (eds.). Correspondencia e
} 


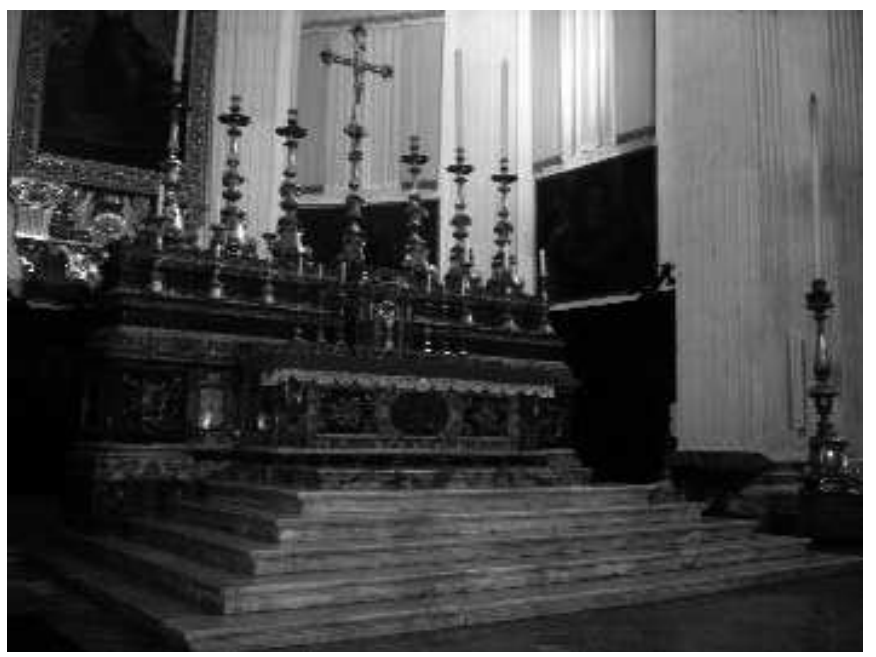

1. Perspectiva del altar mayor de la Iglesia del Salvador en Bolonia. Obsérvese su configuración acorde a las directrices de S. Carlos Borromeo.

de instruir en los contenidos y dimensión mística del misterio sacramental a una multitud en honor a la verdad escasamente sensible ante los refinamientos intelectuales, explica la acción y el efecto desbordante que, ya desde el mismo período medieval, arropará la presentación pública del Sacramento, favoreciéndose su acercamiento a los sentidos mediante exposiciones, fiestas, funciones y procesiones. En el transcurso de estos acontecimientos, la nívea blancura de la Hostia consagrada despunta en el traslúcido viril que, semejante a una cápsula cristalina, la recluye del resto del mundo, al tiempo de mostrarla aprisionada entre los metales y piedras preciosas de los edificios de oro y plata construidos para ella por las fábricas insólitas de tabernáculos, expositores, ostensorios, retablos y custodias ${ }^{11}$. La fenomenología descrita dejaría huella indeleble en el concepto quinientista y seiscentista del templo, si bien con ciertas precisiones formales y conceptuales altamente significativas que dejaron su oportuno reflejo teórico en la literatura artística del momento [1].

En efecto, evaporada ya la carga poética y mística del Humanismo renacentista, se impuso el pragmatismo y el ordenamiento litúrgico de la Reforma Católica

Integración de las Artes. Actas del XIV CEHA. Málaga, Universidad, 2003, págs. 225-243 y “Eclosión, auge y pervivencia de una asociación del Barroco: la Hermandad Sacramental de los Santos Mártires y la promoción arquitectónica en la Málaga del siglo XVIII”, Boletín de Arte nº 25, Málaga, 2004, págs. 249-272.

11 SÁNCHEZ LÓPEZ, J.A.: "Edificios de Oro y Plata. Las maquetas de una arquitectura imposible", Boletín de Arte $\mathrm{n}^{\circ} 16$, Málaga, 1995, págs. 139-158. 
teorizado por Panvinio en el De praecipuis urbis Romae Sanctioribus basilicis (1570) y Pietro Cattaneo en I quattro primi libri d'architettura (1554 y 1567); pero, sobre todo, por las Instructiones Fabricae et Supellectilis Ecclesiasticae o recomendaciones para la fábrica de los templos del Arzobispo de Milán, Carlos Borromeo, publicadas en 1577. Por tanto, y ante la nueva situación, los edículos sacramentales tenderían a abandonar su posición central y dominante de los espacios sagrados para retranquearse al fondo del presbiterio, perdiendo así su comunión simbólica y cósmica con la cúpula12. No en balde, el enérgico cardenal aconseja que toda iglesia cuente con un lugar de proporciones lo suficientemente extensas para que, según la medida y la forma prescrita, puedan edificarse decorosa y aptamente una capilla y un altar, siendo deseable que el muro admita la apertura de una concavidad en forma de hemiciclo o ábside en la cabecera -y por extensión en los laterales- para fijar en ella el $a \operatorname{ltar}^{13}$. Además de habilitar el espacio necesario, Borromeo reclama la dignificación y preeminencia del Altar mayor mediante tres o cinco gradas ${ }^{14}$. Bajo la clave del arco abovedado se reservará el sitio de la imagen crucificada. Realizada en ricos metales o esculpida en uno u otro género de leño ${ }^{15}$, la Cruz figurará escoltada por seis grandes candeleros, al tiempo que el tabernáculo eucarístico preside el altar, adherido con solidez al bloque del ara y bien ensamblado entre sus partes, revelando a todos la artisticidad y riqueza preciosa de su labra esculpida y cincelada en materiales nobles y las excelencias de su fábrica arquitectónica -y esta vez sí- de planta octogonal o redonda, en la medida que parezca más elegante y "religiosamente" apropiada para la fábrica de la iglesia ${ }^{16}$.

La observancia de ese 'decoro' no obsta para que los arquitectos no continuasen 'recreándose' en las posibilidades especulativas brindadas por el diseño del

12 SÁNCHEZ LÓPEZ, J.A.: "Malos tiempos para la lírica. Decoro arquitectónico y controversia litúrgica en torno al ciborio y tabernáculo de la Colegiata de Santa María de Antequera”, en Estudios de Historia Moderna. Homenaje a la Doctora María Isabel Pérez de Colosía Rodríguez. Málaga, Universidad-Equipo Interdisciplinar "Málaga Moderna", 2006, págs. 539-595.

13 Quaecunue etiam ecclesia, sive tribus navibus, sive una tantum constat, extra suae cappelae maioris situm, ab utriusque lateris capite locum habet, sicut supra moxpraefinimus, ita patentem, ubi in uno et altero item latere, pro modo formaque prescripta, cappella et altare decore apteque exaedificari possit, aut ad hemicycli saltem speciem parietis concavitas fieri queat, cui altari innixum haereat. Vid. BORROMEO, C. : Instructiones Fabricae et Supellectilis Ecclesiasticae Caroli S.R.E. Cardinalis Tituli S. Praxedis. Carlos Borromeo. Instrucciones de la Fábrica y del Ajuar Eclesiásticos. México, UNAM, 1985, pág. 21.

14 Praeterea,, si a lateribus et a fronte spatii satis datar, gradus tres adhibeantur, unus scilicet, quem per se bradella facit, tum alii duo, ipsa bradella inferiores: qui duo e marmore solidove lapide fieri debent (...) Ubi vero, pro ecclesiae altarisque maioris amplitudine, gradus plures esse possunt, ibi quinque extrui poterunt latitudine et altitudine mox praescripta. Ibídem, págs.17-18.

${ }^{15}$ Sub ipso autem cappellae maioris fornicato arcu, in omni ecclesia, praesertim parrochiali, crucis et Christi Domini in ea affixi imago, ligno aliove genere, pie decoreque expressa, proponatur apteque collocetur. lbídem, pág. 18.

16 Primo illud in ecclesiis insignioribus, ubi potest, e laminis argenteis aut aeneis, iisdemque inauratis, aut e marmore pretiosiori, fieri decens est. Quod tabernaculi opus, polite elaboratum et apte beneque Inter se compactum, piis item mysteriorum passionis Christi Domini imaginibus exculptum, et inaurato artificio certis locis, periti viri indicio, decoratum, religiosi et venerando ornatos formam exhibeat (...) Forma vel octangula, vel rotunda, prout decentius et religiosius accomodata videbitur ad ecclesiae formam. In summo tabernáculo sit imago Christi, gloriose resurgentis vel sacra vulnera exhibentis. Ibídem, págs. 18-19. 
tabernáculo en su condición de edificio fantástico y quimérica microarquitectura, sin descartar ese componente de cierto 'divertimento' personal, en su día bellamente descrito por Chueca, al sentenciar:

"Siempre estos pequeños tabernáculos de altar nos han hablado de íntimas preferencias de los arquitectos, que en menudo y caprichosamente podían en ellos descolgarse, como no hubieran podido hacerlo en obras grandes, más comprometidas y costosas. [...] El arquitecto apenas puede, como lo consiguen el poeta, I músico y el pintor, entrar con su arte en aquel reino de la fantasía, donde los recuerdos se cruza, funden y entremezclan para prender algunos en un figurativo momento de íntima evocación. Sólo en estos modelos de juguete, pequeños resquicios del arte, puede el arquitecto abandonarse a su fantasía y a sus recuerdos [...] dejándonos una confesión íntima de arquitectura"17.

3. En busca del arca perdida: la Catedral de málaga y la UTOPIA DEL TABERNÁCULO.

Aún cuando en la Catedral de Málaga no se optase por el modelo de rotonda diseñado por Diego de Siloé para la seo granadina ${ }^{18}$, era evidente que la configuración de la Capilla Mayor favorecía, a todas luces, la ubicación de un tabernáculo ${ }^{19}$. Su arquitectura diáfana que sirve de 'transparente' telón a la manifestación e 'invasión' metafísica de la luz blanca, su evidente verticalismo de consciente resabio gótico, su concentrado centralismo, la relectura 'heterodoxa' del 'alzado siloesco' verificada por Diego de Vergara en su esbeltísimo andamiaje constructivo y su carácter programático de sentido cristológico eran motivos más que suficientes como para refrendar la apuesta por el altar de vanguardia. Al ser presentado sobre el ara, el Sacramento sería visible desde todos los puntos de la girola, asumiendo el tabernáculo las connotaciones simbólicas de lazo de unión entre el Cielo y la Tierra, representados ambos en los programas escultóricos y pictóricos situados a distintas alturas de la propia Capilla Mayor20.

17 CHUECA GOITIA, F.: “Ventura Rodríguez y la Escuela Barroca Romana”,en El arquitecto D. Ventura Rodríguez (1717-1785). Madrid, Museo Municipal-Concejalía de Cultura Ayuntamiento, 1983, pág. 83.

18 ROSENTHAL, E.E.: La Catedral de Granada. Un estudio sobre el Renacimiento español. Granada, Universidad-Diputación Provincial, 1990, págs. 142-152.

19 GONZÁLEZ TORRES, J.: "El tabernáculo. Hito sacramental y referente espacial en las Catedrales andaluzas", en RAMALLO ASENSIO, G. (coord. y ed.): Actas del Congreso "El comportamiento de las Catedrales españolas. Del Barroco a los Historicismos". Murcia, Universidad-Fundación Cajamurcia-Consejería de Educación y Cultura, 2003, págs. 313-325.

20 CAMACHO MARTÍNEZ, R.: Arquitectura y Símbolo. Iconografía de la Catedral de Málaga. Málaga, Real Academia de Bellas Artes de San Telmo, 1988, págs. 39-42 y SÁNCHEZ LÓPEZ, J.A.: "Rex Martyrum, Sol Salutis. El Palacio Cristológico", en: ARCOS VON HAARTMAN, E. (coord.).: Retrato de la Gloria. Restauración del Altar Mayor de la Catedral de Málaga. Barcelona, Winterthur, 1999, págs. 15-34. 
Así las cosas, entre 1587-1588 el obispo Luis García de Haro ordenaba dar por concluidas las obras del templo y acometer las labores decorativas y de habilitación para su precipitada consagración el 31 de agosto de 1588. El prelado justificaba tan drástica decisión en el 'parasitismo' que, a su modo de ver, había ejercido desde 1549 la fábrica del primer templo al 'engullir' la práctica totalidad de las sumas disponibles, en franco detrimento de las fábricas menores de la diócesis. Sin embargo, García de Haro, hombre temperamental y esforzado militar en su juventud, también mostraba su talante más amable como individuo culto y generoso mecenas, al costear de sus rentas todo lo necesario para terminar de ornamentar la Capilla Mayor. En este capítulo entraría en escena la interesante figura del pintor de Saluzzo, Cesare Arbassia ${ }^{21}$. Al parecer, el italiano diseñó, pero, sin duda, ejecutó y pintó un hermoso tabernáculo de madera dorada y jaspeada, cuyo aspecto presentaba -a juzgar por la documentación- un desarrollo arquitectónico ascensional, bastante afín al esquema turriforme propio de las custodias procesionales y túmulos funerarios, al estructurarse en tres cuerpos superpuestos, el último de los cuales sustentaba un organismo cupulado. Sin duda, debía resultar un conjunto impresionante y de enormes proporciones que, además, participaba de un complejo simbolismo eucarístico fundamentado en un programa -cuyo mentor identificamos en el mismo obispo Luis García de Haro, a base de jeroglíficos y alegorías, prefiguras bíblicas, personajes del Antiguo y Nuevo Testamento, los Apóstoles e ideas expresadas mediante inscripciones latinas 22 .

Sin embargo, el profundo disgusto con que el Cabildo recibió la paralización de la Catedral y su obligación de acatarla por decreto al hacerse irrenunciable la imposición de la voluntad episcopal, no le hizo ver con buenos ojos el hermoso tabernáculo de Cesare Arbassia. Si a ello unimos la intención inicial de acometer la realización del edículo en materiales preciosos -mármoles y bronce- la corporación contaba con la excusa perfecta para retirar del culto y, sobre todo de su vista, la memoria de un prelado 'maldito' al que nunca perdonaron, pese a haber regalado un elemento cuya belleza no pudo salvarlo al haberse convertido para los capitulares en testimonio vivo de algo y de alguien que no les traía, precisamente, buenos recuerdos. Con todo, las discusiones y dudas en torno a la traza del tabernáculo continuaron sucediéndose a lo largo del Seiscientos, complicándose aún más la situación por la existencia en esta época de dos trazas dadas por el jesuita Francisco Díaz de Ribero (h. 1659-1663) y Alonso Cano (1665), esta última documentada en su día por Rosario Camacho ${ }^{23}$. El siglo avanzaba y la erección del edículo amenazaba con con-

21 BLÁZQUEZ MATEOS, E. y SÁNCHEZ LÓPEZ: Cesare Arbassia y la Literatura artística del Renacimiento. Salamanca, Universidad, 2002, págs. 67-69.

22 SÁNCHEZ LÓPEZ, J.A : "Non Vos Delerinquam. La Catedral de Málaga y un sueño del Renacimiento", en Espacio, Tiempo y Forma, Serie VII-6, 1993, págs. 221-240.

23 CAMACHO MARTíneZ, R.: "Alonso Cano y Málaga", en Alonso Cano. Virgen del Rosario. Madrid, Fundación Argentaria, 1997, págs. 14-18. 
vertirse en una empresa traumática detenida por la inercia de quienes titubeaban entre sendos modelos. Por fin, y ya casi en la última década del XVII, el Cabildo se decidía a terminar con semejante estadio de provisionalidad, embarcándose en la ejecución de una gigantesca máquina de madera, cuya estructura ocultaba, al parecer y casi por completo, el alzado de la Capilla Mayor. Si el seguimiento de uno u otro proyecto todavía arroja incógnitas, lo cierto es que la realización material del tabernáculo correspondió a dos personajes, cuya vinculación con la problemática de la arquitectura efímera parece proporcionar la clave definitiva del asunto. Nos referimos al arquitecto de madera José Fernández de Ayala y el escultor Jerónimo Gómez Hermosilla quien ejecutó, al menos, las esculturas patronales de San Ciriaco y Santa Paula, San Luis de Tolosa y San Sebastián ${ }^{24}$. Según documentase Juan Antonio Sánchez, ambos figuran en la nómina de artífices empleados en la construcción del tabernáculo a 28 de mayo de 168925 .

Tanto Gómez como Ayala aplicaron en su realización la experiencia previa volcada en los aparatos efímeros del Corpus y las exequias reales ${ }^{26}$. A nuestro entender, y por las referencias documentales y literarias conservadas, la fisonomía del conjunto debió fusionar los rasgos más llamativos de las trazas de Cano y Díaz de Ribero, reinterpretados por Gómez y Ayala acorde a su óptica personal con criterio propio. De esta manera, un mecanismo de torno permitía el giro ilusionista del manifestador en las solemnidades pertinentes, constituyéndose en el núcleo simbólico de un monumental despliegue arquitectónico, semejante a una gran mampara poligonal, que se adaptaba como un retablo parietal a la estructura semidecagonal de la cabecera, conservando al mismo tiempo, el espíritu centralizado de un templete. Concluido en su talla, ensamblaje y escultura este tabernáculo quedó sin dorar, lo cual debió influir en el ánimo de los capitulares para sustituirlo en el siglo XVIII. Con esta nueva vuelta de tuerca, no sólo se retornaba a la idea inicial de ejecutar el edículo en mármoles, sino que reaparecían las aspiraciones utópicas de materializar el edificio perfecto en una microarquitectura exenta. Como veremos seguidamente, es aquí, en esta tesitura, donde José Martín de Aldehuela, sin reparar en medios ni esfuerzos, estuvo determinado a desempeñar un papel esencial en esta historia que, para su pesar y contra su voluntad, tampoco él cerraría.

24 Después de desmantelarse el tabernáculo, esta escultura pasó en fecha indeterminada a la Capilla del Colegio Seminario de San Sebastián, resultando destrozada en los años treinta. Posteriormente fue muy restaurada por José Navas Parejo, José Martín Simón y Juan de Ávalos, quien incluso se atribuyó la autoría. Hoy permanece en la Catedral, donde también se conserva San Luis de Tolosa. Los Mártires Ciriaco y Paula fueron cedidos para presidir el retablo mayor de la parroquia de su nombre, tras la desaparición de las imágenes dieciochescas propias en 1931.

25 Archivo Temboury, leg. 67: Edificios Religiosos, secc. Catedral, asunto: Tabernáculo.

26 PÉREZ DEL CAMPO, L. y QUINTANA TORET, F.J.: Fiestas barrocas en Málaga. Arte efímero e ideología en el siglo XVII. Málaga, Diputación Provincial, 1985, págs. 121-133. 


\section{Cuenca.}

4. Obra retablistica de José Martín de Aldehuela en Teruel y

José Martín de Aldehuela (Manzanera,Teruel, 1724 - Málaga,1802) inició su formación en un ámbito familiar ya que debió trasladarse desde muy joven a Teruel donde se formaría con un tío suyo, maestro carpintero, quien le introdujo en un campo técnico que él amplió a la arquitectura de retablos, trabajando con José Corbinos y perfeccionándose con Francisco de Moyos, en Aragón, como indicó Ceán Bermúdez 27 . Asimismo éste indica que una vez examinado y aprobado de maestro de obras se puso a su cuidado la iglesia y colegio de los jesuitas de Teruel que se realizaba con el patrocinio del Obispo Pérez Prado28. Es posible que se incorporase a ella a través de la realización de los retablos, ya que era muy joven para dirigir una obra arquitectónica de esta envergadura; tal vez la responsabilidad de Aldehuela empezase con la retablística extendiéndose después a la decoración de la iglesia, pero no cabe duda de que trabajó en ella puesto que la Compañía le adeudaba la cantidad de 600 libras todavía en $1752^{29}$.

Pero si no se ha conservado la arquitectura de esta iglesia, menos aún su amueblamiento, aunque conocemos su interior y retablo mayor a través de una fotografía del Instituto Amatller, y a través de sus formas vemos como este magnífico retablo debió marcar su carrera en la retablística ${ }^{30}$.

De los otros retablos que José Martín realizó para Teruel hay escasos testimonios, pero documentalmente sabemos que los clérigos de San Juan y el convento de Santo Domingo le adeudaban dinero, que tenía que ser por pago de obras, y en este último caso, al menos, serían retablos pues se reseña también una deuda importante de madera 31

A la parroquia de San Andrés se trasladaron los retablos de la desaparecida iglesia de San Juan. El mayor parece que se realizó hacia 1750, y se ha relacionado con el círculo de escultores del retablo de la Compañía, sospechándose incluso de Aldehuela como su proyectista 32 . Con su hornacina central flanqueada por pilastras con querubines, que apoyan en pequeños atlantes, y columnas con guirnaldas que muestran influencia de la custodia (1742), Ilaman la atención los remates de éstas, con pequeñas esculturas y el pabellón con dosel que cobija el grupo de la Visitación. Además el engarce del remate con la bóveda y los bocelones concéntricos que, enla-

27 LLAGUNO Y AMIROLA, E.: Noticia de la arquitectura y arquitectos de España desde su Restauración ilustradas y acrecentadas con notas, adiciones y documentos de J. A. CEÁN BERMUDEZ, vol. IV, Madrid, 1797 Ed, facsímil, Turner, 1977, vol. IV, pág. 296

28 SEBASTIÁN LÓPEZ, S. y SOLAZ, A.: Teruel Monumental. Teruel, Instituto de Estudios Turolenses, 1969, pág. 135.

29 .A.H.P.M. (Archivo Histórico Provincial de Málaga) Esch. M. J. Romero, leg. 3270, fol. 1160.

30 MORA PASTOR, J.: Aproximación a la figura del arquitecto José Martín (Aldehuela) y su obra en Cuenca. Cuenca, Diputación Provincial, 2005, pág. 78.

31 A.H.P.M. Escr. M. J. Romero, leg. 3270, fol. 1160 y $1159 \mathrm{v}$.

32 SEBASTIAN, S. y SOLAZ, A.: Op. cit., pág. 191 
zando con los entablamentos partidos, rematan la hornacina en un ritmo muy similar, aunque invertido, al de la fachada de la iglesia de San Pablo de Cuenca, lo relacionan con el estilo de Aldehuela.

También procedente de San Juan es el retablo del Cristo de las Misericordias o de los Membrillos. De "planta movida y gusto borrominesco" aunque de menos talla y adornos, alberga al citado Cristo en una hornacina cruciforme, flanqueada por columnas corintias entre las que el fondo se curva suavemente y sostienen un pequeño frontón triangular, rematándose con elegante penacho. Evidentemente este retablo, aunque más sencillo, está en la misma línea del que Aldehuela realizara para la capilla del Pilar de la Catedral de Cuenca y su diseño, que parece responder a una etapa posterior a su estancia en Teruel, pudo enviarlo residiendo ya en aquella ciudad. La capilla del Cristo de la Misericordia sabemos que fue realizada por su hijo, siendo párroco de la iglesia, el cual había hecho también cuatro retablos para la misma. En cualquier caso la línea estilística es común, lo cual podría reforzar las relaciones con el arquitecto.

El retablo mayor de la parroquia de San Miguel, costeado por el obispo Pérez Prado, se realizó entre 1750-1755 y es un conjunto triunfal que destaca por la riqueza de su fondo ideológico y se ha relacionado con Francisco de Moyos ${ }^{33}$; no obstante el movimiento que le imprimen el cuerpo central y los laterales cóncavos que enlazan con el remate conchiforme, el énfasis de las columnas destacándose del fondo al modo de los modelos del padre Pozzo, los frontones curvos cortados convertidos en aletones, la profundidad de las hornacinas, el tipo de peanas, la disposición de las esculturas rematando pequeñas columnas o la coronación con el grupo de la Trinidad sobre una esfera sugerida, nos lleva a pensar de nuevo en José Martín de Aldehuela.

Cuando José Martín llegó a Cuenca, en 1749, debía tener aproximadamente venticinco años y aunque no podría contar con una sólida experiencia, debía venir precedido de gran fama en cuanto a su habilidad con la talla y la composición retablística.

También es Ceán quien nos indica que fue llamado por D. Álvaro Carvajal y Láncaster, arcediano de Moya y hermano de quien luego sería obispo de Cuenca, quien lo solicitó para incorporarse a la obra del Oratorio de San Felipe Neri, y en esta ciudad permaneció durante muchos años, llevando a cabo una obra importante tanto en arquitectura como en la carpintería de retablos.

Ponz señala que realizó los retablos de la parroquia de San Pedro ${ }^{34}$, así como el de San Gil o el de la Merced en la parroquia de Huete, ya más tardío ${ }^{35}$. Y en la iglesia de las Petras, convento de San Pedro Justiniano, donde intervino en las

33 SEBASTIAN, S. y SOLAZ, A.: Op. cit. págs. 201-204

34 PONZ, A.: Viaje de España, 1774. Madrid, Aguilar, vol. III, 1988, pág. 536.

35 MORA PASTOR, J.: Op. cit. pág. 122. MARASSA PABLOS, C.T.: "El retablo de la Merced de Huete, obra de José Martín de Aldehuela", Cuenca n² 28, 1986, págs. 91-94. 
obras de la iglesia en 1761, también ejecutó los retablos, siguiendo trazas de Alejandro González Velázquez y Ventura Rodríguez, aunque posiblemente introdujera elementos de su propio diseño 36 .

En la Catedral de Cuenca fue donde llevó a cabo un trabajo más continuado, además el contacto que en este templo, a partir de 1753, tuvo con Ventura Rodríguez fue fundamental para la evolución de su estilo que, sin abandonar totalmente las fórmulas del rococó francés y centroeuropeo, derivó francamente hacia los cánones del barroco romano que tan bien había asimilado el maestro de Madrid ${ }^{37}$. En 1764, se realizó el retablo de la sacristía mayor con un cuerpo superior y los documentos confirman que fue obra de José Martín ${ }^{38}$, pero también los detalles estilísticos no dejan lugar a dudas, contrastando con la parte inferior que responde al barroco de comienzos del siglo XVIII con columnas salomónicas y abundante hojarasca que cobijan a la Dolorosa y la Virgen de Belén de Pedro de Mena así como otros cuadros de Pedro Atanasio Bocanegra. También modificó, imprimiéndole un aire más rococó, el retablo de Santiago y retocó el de la Reliquia (lo que supondría otra fuente para su conocimiento del estilo de Ventura Rodríguez) ${ }^{39}$.

En 1767 un incendio que afectó al coro, órganos y bóvedas motivó una intervención más constante del maestro, realizando parte de la sillería coral y las cajas para el nuevo órgano mayor y las del menor, que fue restaurado.

A partir de esas fechas sus trabajos en la Catedral se multiplican y otros retablos son obra enteramente suya. En 1770 realizó el de la Magdalena, de madera dorada y policromada, el de Santa Rosa está documentado como obra suya y el de San Antolín, con querubines y capitel ménsula con fina hojarasca, también se le asigna ${ }^{40}$. En 1773 cobró la hechura del retablo de Santa María del Alba, del que se especifica que realizó incluso las esculturas de las santas Lucía y Apolonia, ya que la titular es una imagen de la Virgen de finales del XV41. El retablo, en madera policromada, adaptado a un ángulo de la catedral, con un fuerte movimiento y fingida profundidad, presenta columnas de orden compuesto y se corona con un ático para el emblemático jarrón de azucenas rematado por una gloria de angelillos.

Entre los encargos particulares para la Catedral, hay una obra de especial interés porque resume en una capilla, "pequeño templo en miniatura" como la designó Chueca, el concepto del espacio y la ornamentación de José Martín. La capilla de la Virgen del Pilar que se debe a la devoción del canónigo D. Diego Luyando, es un

36 PONZ, A.: Op. cit. pág. 538. BARRIO MOYA, J.L.: Arquitectura barroca en Cuenca. Madrid, Universidad Complutense, 1991, págs. 599-605

37 CHUECA GOITIA, F.: "José Martín de Aldehuela. Datos para el estudio de un arquitecto del siglo XVIII". Arte Español, XV, 1944, pág. 18. CAMACHO MARTíNEZ, R. Málaga Barroca. Arquitectura religiosa de los siglos XVII y XVIII. Málaga, Diputación, Colegio de Arquitectos y Universidad de Málaga, 1981, págs. 99.

38 . BERMEJO DIEZ, J.: La Catedral de Cuenca. Cuenca, Caja de Ahorros Provincial, 1977,

pág. 296.

39 MORA PASTOR, J.: Op. cit, pág. 56.

40 .BERMEJO DÍEZ, J.: Op. Cit., págs. 393, 60 y 56.

41.MORA PASTOR, J.: Op. cit, págs.. 187-199. 
espacio ingrato, junto a la puerta, donde realizó Aldehuela una obra pequeña (6x3,50ms.) pero logradísima, "el vértice a donde llegó en Cuenca la evolución de Martín de Aldehuela"42, y que interesa especialmente en esta relación porque su retablo inicia la tipología de pequeños templetes que derivarían hacia la tipología de tabernáculo. Su capilla mayor enlaza con el espacio oval del trasaltar, unidos ambos por el movido retablo tras el que se abre un transparente, coronando la bovedilla abocinada del primero otro óculo que permite un doble juego de la luz. El retablo, con mesa de altar y frontal de jaspes, es de madera simulando piedra y estuco, adaptado a la forma cóncava de la capilla y su alzado de columnas corintias proyecta el volumen central hacia el exterior formando una especie de camarín que cobija a la imagen de la Virgen. Cubierto con bóveda oval calada con la gloria del Espíritu Santo, en

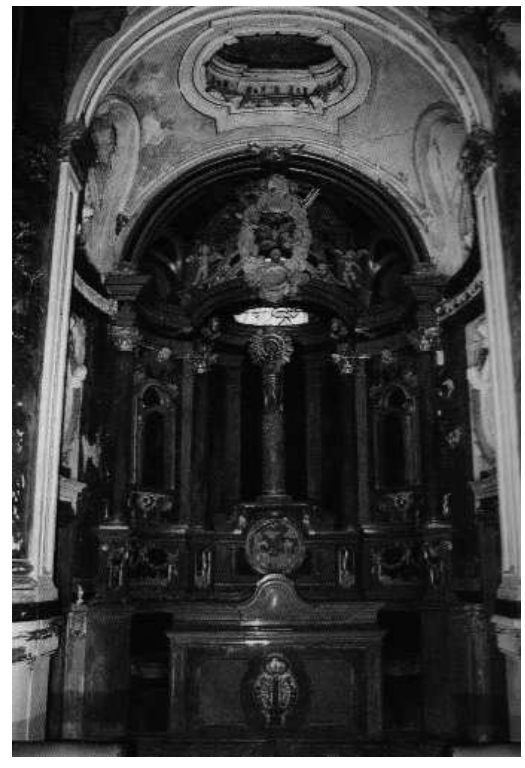

2. Catedral de Cuenca. Capilla de la Virgen del Pilar.

las hornacinas laterales, rematadas por movidos tornapuntas, se encuentran las imágenes de San Juan y el Niño Jesús, obras de napolitano Fumo que también donó el canónigo Luyando [2].

Más ligero, rico y escenográfico es el tabernáculo de la Virgen de la Luz, en la iglesia de San Antón de Cuenca. Un arco con la inscripción ELEGI SANCTIFICAVI LOCUM ISTUM da acceso al ante-camarín, elíptico, ocupado por este aéreo baldaquino formado por columnas de orden compuesto con transparente para el medallón de la Trinidad y cubierta calada rematada por jarrones y guirnaldas que forma un magnífico expositor para la Virgen, muy en la línea de la capilla que Ventura Rodríguez acababa de realizar para la Virgen del Pilar de Zaragoza. Aquí, en Cuenca, la sugestión por el adorno, la cargazón ornamental de los estucos, los dorados, los airosos remates, que completan el programa iconográfico mariano, contribuyen a trasformar este espacio en un auténtico teatro litúrgico que pregona la santidad del espacio presidido por la Virgen de la Luz.

La capilla de la Virgen del Rosario en el convento de dominicos de San Pablo, se realizó siguiendo las trazas de José Martín aunque llevó a cabo la ejecución Mateo López ${ }^{43}$. Dispuesta en la iglesia que edificaron Pedro y Juan de Alviz a partir

${ }^{42}$ CHUECA GOITIA, F.: Op. cit. pág. 23.

${ }^{43}$ Archivo de la Academia de Bellas Artes de San Fernando (A.A.S.F.) leg. 43-1/1. 
de $1523^{44}$, forma un conjunto con un tramo cuadrangular de acceso, un espacio oval con cúpula con su eje mayor perpendicular a la dirección axial de la capilla y el camarín propiamente dicho, conjunto que exteriormente constituye un volumen colgado sobre la hoz del Huécar.

A la altura del crucero, en el brazo izquierdo, los pilares renacentistas del templo se han transformado al superponerle un segundo arco sobre capiteles corintios con querubines, cubriéndose el tramo cuadrangular al que da acceso con bóveda de medio cañón con lunetos que flanquean un medallón de estuco, polilobulado con angelitos en los extremos y en cuyo interior hay un rosario del que cuelgan tres medallones con las advocaciones de la Virgen en sus misterios gozosos, dolorosos y gloriosos; el espacio elíptico de la capilla se articula en su alzado entre columnas corintias en un triple registro de dos pisos separados por finos baquetones con cintas enrolladas y coronados por capitel ménsula con querubín, conservándose el escudo dominico en el centro y una placa de rocalla en el entablamento con letras que componen el AVE MARIA.

Al fondo, entre pilastras afrontadas con capitel ménsula se alza el pequeño baldaquino de madera que cobija a la Virgen del Rosario, también oval, con capiteles de orden compuesto que sostienen movida cornisa con entramado abierto en su cubierta, superponiéndose al espacio real del camarín que juega de fondo; de planta oval cubierto con bóveda vaída está perforado en su testero con óculo polilobulado que forma el transparente.

Durante su estancia en Málaga también diseñó retablos, pero fue más importante su obra arquitectónica y de ingeniería; no obstante cabría citar el de San Sebastián en la Catedral, el de la iglesia de San Agustín y ya en la provincia el de la parroquia de Nerja o el mayor de la iglesia de los Trinitarios de Antequera. De todos ellos sólo en el de San Agustín juega con el espacio y los volúmenes para disponer un camarín que, a través de las columnas que sostienen la bóveda, se proyecta sobre el espacio de la capilla mayor, al modo de esos altares baldaquinos, aunque las formas son mucho más clásicas 45 .

\section{José Martín de Aldehuela y el proyecto de tabernáculo} para la Catedral de Málaga.

José Martín de Aldehuela fue llamado a Málaga por D. José Molina Lario, también turolense y nuevo obispo de esta diócesis desde 1776, para realizar las cajas de los órganos, cuyo proyecto presentó en noviembre de 1778 y ya se estableció en Málaga hasta su muerte, en 1802, llevando a cabo una notable actividad no sólo en

\footnotetext{
${ }^{44}$.ROKISKI LÁZARO. Ma L.: Arquitectura del siglo XVI en Cuenca. Diputación Provincial 1985, pág. 97.

45 CAMACHO MARTÍNEZ, R.: "Aportaciones a la obra retablística de José Martín de Aldehuela", Boletín de Arte $\mathrm{n}^{\circ}$ 9, Málaga, 1988, págs. 183-199.
} 
la Catedral sino en todo el territorio. Pero entre otros trabajos para este templo, realizó un diseño para el tabernáculo, lo que había sido y será, según dijimos, la gran utopía de la Catedral de Málaga46.

Al iniciarse el XVIII, proseguía la búsqueda del modelo ideal. Así las cosas, en 1724 , se daba cuenta del descubrimiento de una cantera de jaspe encarnado en Casabermeja capaz de suministrar el material precioso requerido por el proyecto. La traza se confió indirectamente a José de Bada, aunque lejos de exigírsele una creación original, el Cabildo le sugería subordinarse por completo al diseño dado en su día por Juan de Herrera para el tabernáculo de la Basílica de El Escorial. Tras los últimos proyectos que realizaran José de Medina en 1768, Antonio Ramos en 1770 y el remitido en 1774 por Francisco Calvo Bustamante desde Jaén, a partir de 1776 el Cabildo se inclinaba por realizar la obra en plata, aunque dos años después volvieron a coincidir en los jaspes como el material más adecuado. $Y$, pensando en una obra suntuosísima, contactaron con Ventura Rodríguez, a quien, en 1778, se le proporcionaron todos los diseños reunidos hasta el momento, junto al plano de la capilla mayor realizado por Ramos. Pero los encargos a Ventura Rodríguez eran tantos, desde toda la Península y desde diferentes instancias, que pasado un tiempo más que prudencial y convencido el Cabildo de que las muchas ocupaciones de Rodríguez no le permitirían acometer el proyecto 47 , hablaron con José Martín de Aldehuela, quien conociendo las apetencias de los capitulares contaba ya con un proyecto del edículo que presentó en el cabildo de 4 de julio de 1781. En su exposición insiste, recordando que se había mandado a Rodríguez planta para que conociera la disposición de la capilla, en que ha tenido en cuenta las perspectivas visuales desde los vanos de la capilla mayor, de modo que quedaba realzada la posición del tabernáculo y su simbolismo. Tal vez animado por estos argumentos el Cabildo le encargó el traslado del papel a la madera para instalarlo en su sede definitiva y "reconocer práctica y materialmente la destreza y acierto con que parece se ha ideado"48.

Esa maqueta no llegó nunca a obra definitiva, pero al concebirse en escala 1:1 y mimetizar los materiales definitivos con pintura, la basa y barandillas rematadas por bolas a imitación de las obras antiguas y los bronces simulados con aplicaciones de pan de oro ${ }^{49}$, se utilizó como tabernáculo durante casi un siglo, mientras se seguían realizando proyectos que no llegaron a materializarse y que se costeaban de un fondo dedicado a gastos suntuarios 50 . Conocemos su imagen porque se

\footnotetext{
46 Sobre el tema ver el estudio de conjunto de SÁNCHEZ LÓPEZ, J. A.: Historia de una utopía estética: el proyecto de tabernáculo para la Catedral de Málaga. Málaga, Universidad, 1995.

47 Archivo de la Catedral de Málaga (A.C.M.) Actas Capitulares, vol. 53 (1777-1781), fol. 193r.-194r.. El agente de Madrid indica que Rodríguez "para evacuar lo que tiene era menester se volviese cien hombres". Ibídem, fols. 218r.-219r..

48 A.C.M. Actas Capitulares vol 53, fols. 620v.-621r.

49 A.C.M. Cartas y Comunicaciones al Cabildo. Leg. 612, pza. 21. Documentos pertenecientes a José Martín de Aldehuela, maestro de obras menores del obispado de Málaga, 1782-1791.

50 A.C.M., Actas Capitulares, vol. 52 (1773-1776), fols. 356v. y 367r. SÁNCHEZ LÓPEZ, J. A.: Op. cit., págs.
} 


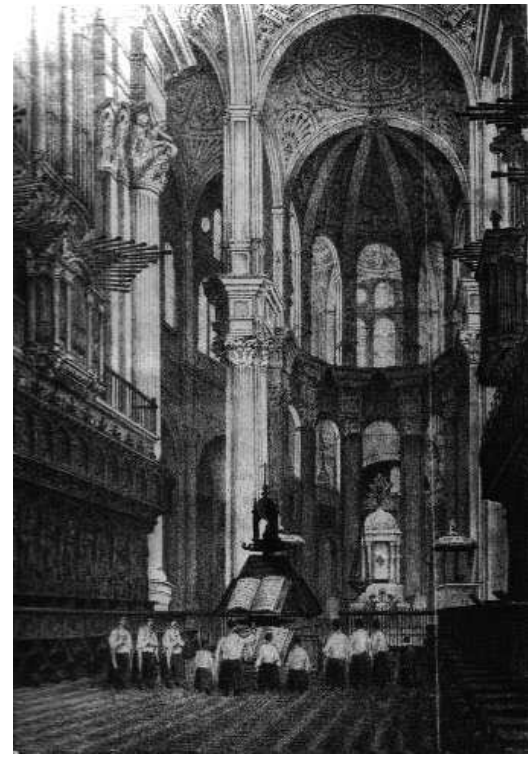

3. Interior de la Catedral de Málaga. Litografía de E. W. Mark en la revista "El Guadalhorce". reproduce en una de las láminas de la revista El Guadalhorce, de 183951 , coronado por el ramo de azucenas, emblema de la Catedral, y dado que el tabernáculo que hoy ocupa el presbiterio de la Catedral es el que se realizó en 1861 por el arquitecto granadino Francisco Enríquez Ferrer, quien había ganado el concurso público convocado en $1851^{52}$, no cabe duda de que este grabado reproduce el "modelo" de Aldehuela [3].

Cuando el tabernáculo de Enríquez Ferrer, ocupó el presbiterio de la Catedral, la maqueta de Aldehuela fue cedida, en enero de 1861, a Rafael Rodríguez quien había construido a sus expensas, y edificado por el arquitecto Cirilo Salinas, un convento para las monjas clarisas, y en la iglesia, que dedicó a la Santísima Trinidad, nombre del barrio en el que se ubica, continuó sirviendo como tabernáculo. A pesar de los destrozos sufridos en la iglesia en la

quema de conventos de mayo de 1931, se conservó este tabernáculo, que fue definitivamente destruido en 1936, aunque lo conocemos por una fotografía del Archivo Temboury53 [4 y 5].

Aldehuela había diseñado en 1781 un templete de planta circular, apoyado sobre una caja cilíndrica en la que se inserta el sagrario, limitado por ocho estilizadas columnas, que se agrupan por parejas en las líneas coincidentes con las diagonales; sobre un amplio entablamento descansa una cúpula de marcadas nervaduras en el trasdós, que contribuían a enriquecer el claroscuro. Su estilo responde plenamente a las normas academicistas y se emparenta con los que realizó en Málaga para el altar mayor de la iglesia de San Agustín (1798-1799) y, sobre todo, para el de San Felipe (1790-1795). Si se compara este último con la maqueta catedralicia de 1781 , se llega a la conclusión de que ambas trazas son casi gemelas, salvo insigni-

82-83. LLORDÉN SIMÓN, A.: Historia de la construcción de la Catedral de Málaga. Colegio de Aparejadores y Arquitectos Técnicos de Málaga, 1988, págs. 269-270. Vid. Archivo Histórico Provincial de Málaga (A.H.P.M.) Escr. Gregorio Martínez de Ribera, fols. 400-409.

51 El Guadalhorce, Imp. del Comercio, Málaga 1839. Tomo 1, nº 42, 22 de diciembre de 1839, págs. 336337.

52 SÁNCHEZ LÓPEZ , J. A.: Op. cit., pág. 119.

53 A.C.M. Actas Capitulares, vol. 69 (1861-1865), fols. 2r. y v. Archivo Temboury (A. T.) foto n 4239. SÁNCHEZ LÓPEZ, J. A.: Op. cit., pág. 147 


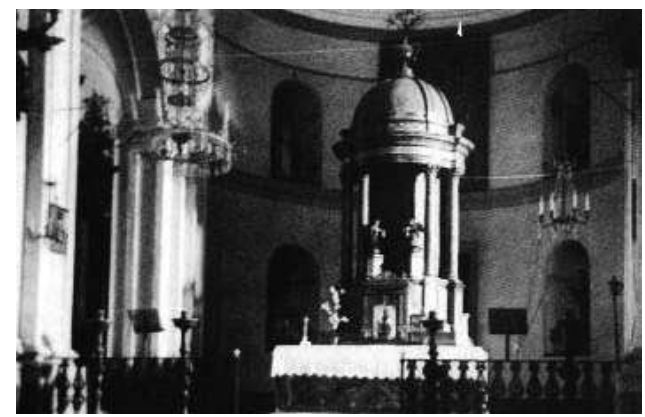

4. $\boldsymbol{y}$ 5. Perspectiva del presbiterio de la Iglesia de la Trinidad anterior a 1931. Preside el altar la maqueta de 1781-1782, de la que puede advertirse un detalle.

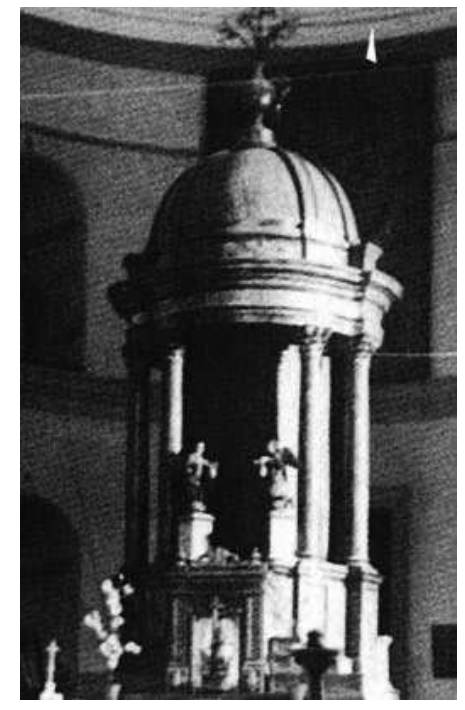

ficantes variantes en el motivo cimeral y la apertura de cuatro arcos apeados sobre ménsulas en la cella del edículo filipense. Tales analogías invitan a preguntarse si Aldehuela aprovechó y recicló para el tabernáculo de San Felipe las pautas 'políticamente correctas', inicialmente ideadas para su homólogo de la Catedral. De todas formas, en todos estos recintos, la presencia de un edículo centralizado refuerza el contenido sacramental del presbiterio y, por extensión, sintoniza con la interesante rehabilitación del ciborium exento verificada por la arquitectura dieciochesca de signo ilustrado. No sólo por reflejar la apetecida pureza estructural y espacial, sino por encarnar los ideales de espiritualidad interiorista, racionalista y profunda tan propia del Siglo de las Luces [6].

Como se ha indicado, el Cabildo mantuvo esa obra como provisional en el altar mayor y siguió encargando proyectos. En 1794, y aprovechando la estancia en Málaga del arquitecto italiano Vicente Mazzoneschi, para realizar el Teatro Cómico Principal, le encargó un nuevo proyecto de tabernáculo, que éste entregó inmediatamente y se comprometió a realizarlo para la Navidad de 179654 . Tal vez no quedase muy convencido el Cabildo, siempre tan dubitativo, y Aldehuela aprovechó la oportunidad para diseñar un nuevo tabernáculo, pues en 21 de junio de 1796 se presentaban dos ideas de éste que, después de ser revisadas por maestros de Málaga y Cádiz, se discutieron en reunión capitular de 16 de septiembre de 179655. Pero el Cabildo de Málaga nunca respetó a los arquitectos vernáculos y entonces decidió

54 A.C.M. Actas Capitulares, vol. 57 (1794-1798), fols. 32r. y v. y SÁNCHEZ LÓPEZ, J. A.: Op. cit., pág. 88

55 A.C.M. Actas Capitulares, vol. 57, fols. 294r. y 326r. 


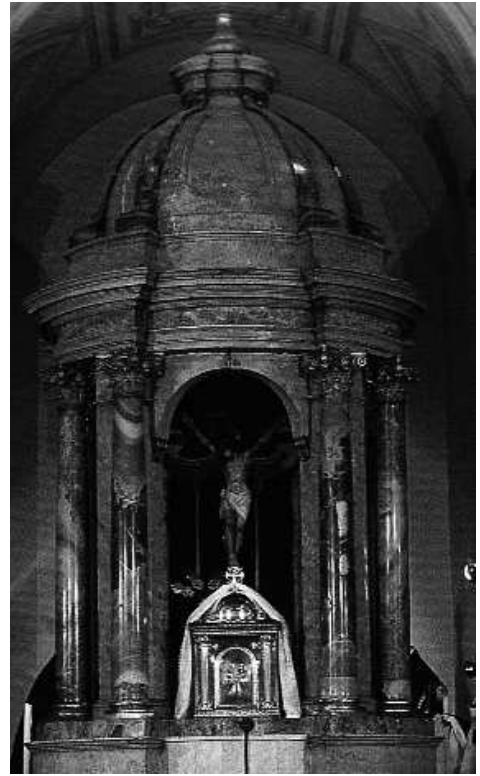

6. José Martín de ALDEHUELA. Tabernáculo de la parroquia de San Felipe. enviar el proyecto a la Real Academia de San Fernando 56 , cuyas normas sobre la revisión de los proyectos de maestros locales, había ignorado cuando le convenía 57. El 17 de octubre de 1796 fueron evaluados por la Comisión de Arquitectura de la Academia, presidida por Juan Pedro Arnal, quien rechazó estas trazas "por defectuosas en sus formas y proporciones y gusto depravado"58. Con ello están rechazando, una vez más, al Barroco; sin embargo el tabernáculo que hemos visto en la litografía de El Guadalhorce, dibujado y grabado por E. W. Mark, no responde a los estilemas del Barroco. Ya se llamó la atención sobre el "sentido peyorativo aplicado por los académicos madrileños a esta propuesta"59. Lo cierto es que el diseño del tabernáculo enviado desde Málaga se rechazó, encargando la Comisión de la Academia uno nuevo a Evaristo del Castillo y Silvestre Pérez, realizando éste un magnífico y frío proyecto del más puro estilo neoclásico60

que, por ende, iba mucho más lejos en sus pretensiones al propugnar una radical repristinación arquitectónica de la Catedral, acompañada de la eliminación del coro, la ubicación del tabernáculo en el corazón del crucero, la construcción de una nueva sillería de mármol y su traslado al presbiterio61.

De colección particular62, recientemente ha llegado a nuestras manos un dibujo de tabernáculo firmado por Aldehuela, que responde a un diseño barroco cla-

56 CAMACHO MARTÍNEZ, R.: "Arquitectos de la Academia de San Fernando en la Málaga del siglo XVIII", Academia. Boletín de la Real Academia de Bellas Artes de San Fernando n 67, Madrid, 1988, págs. 265290.

57 A.C.M. Cartas y comunicaciones al Cabildo. Leg. 314 (1787-1792), pza. 14: Reales Órdenes sobre el funcionamiento de las RR. Academias de San Fernando y de San Carlos sobre aprobación de arquitectos y Maestros de Obras y sobre que no se hagan en las iglesias nuevos retablos de madera.

58 A.A.S.F. 3/86, Actas de las Juntas Generales Ordinarias y Públicas, 1795-1802, fol. 63r. y Tabernáculos 1783-1863. Leg. $234 / 4$ s.f.

59 SÁNCHEZ LÓPEZ, J. A.: Op. cit. pág.92

60 SÁNCHEZ LÓPEZ, J. A.: Op. cit. págs.. 92-106.

61 SÁNCHEZ LÓPEZ, J. A.:"llustración y Utopía: la 'Nueva Imagen' de la Catedral de Málaga y su repristinación arquitectónica, en RAMALLO ASENSIO, G. (coord. y ed.), El comportamiento de las Catedrales españolas. Del Barroco a los Historicismos. Murcia, Universidad, 2003, págs. 141-172.

62 Agradecemos a Blanca Moreno Mitjana que nos haya permitido estudiar y dar a conocer este diseño. Y la ayuda prestada por Amelia Montiel y Eduardo Asenjo. 

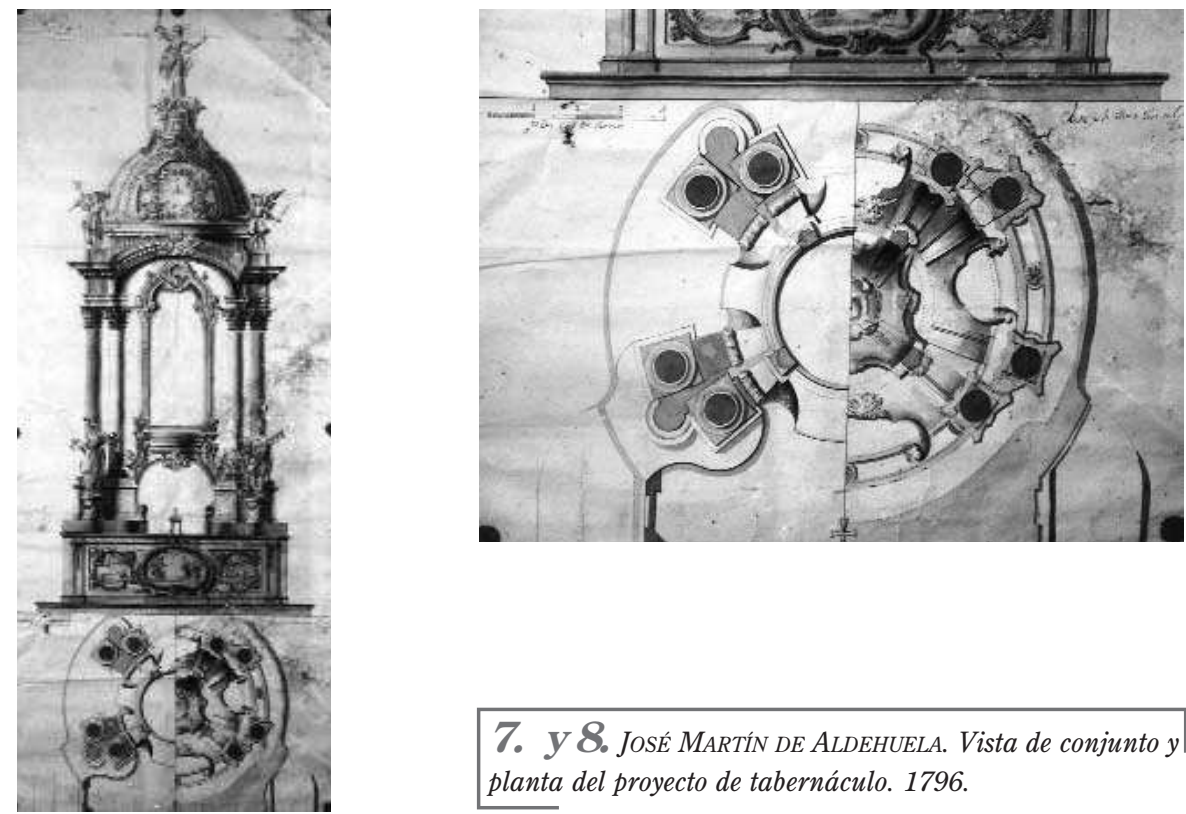

7. $\boldsymbol{y}$ 8. José MARTÍN DE ALDEHUELA. Vista de conjunto y planta del proyecto de tabernáculo. 1796.

sicista con elementos ornamentales rococó y, consecuentemente, menos políticamente correcto con los vientos imperantes. Analizándolo parece más relacionable con su primer estilo y con las obras que realizó nada más llegar a Málaga (cajas de los órganos ${ }^{63}$ o el retablo de San Sebastián de la Catedral), si bien es cierto, y lo hemos comprobado en otras obras, que gustaba de hacer evasiones hacia formas decorativas plasmadas con anterioridad. Si fue éste el enviado a la Academia de San Fernando, y debía serlo, evidentemente la Comisión de la Academia rechazaba al Barroco que aquí se muestra [7].

Es un plano completivo $(103 \times 46 \mathrm{~cm}$.) que presenta el alzado de un tabernáculo, insertándose en la parte inferior un corte por la base y otro por la cubierta. Está firmado en la intersección de ambos dibujos, a la derecha, por "José Martín de Aldegüela". Al otro lado, la escala en pies castellanos.

La planta muestra el arranque de las columnas, con sus basas cuadradas alrededor del círculo, situadas en cuatro grupos de dos, que no se disponen en paralelo sino antepuestas y ligeramente sesgadas; en el ángulo que dejan se señala el corte de otra columna truncada, que es el pedestal, sobre el que se alzan, en los frentes, las imágenes de los Santos Mártires Ciriaco y Paula, patronos de la ciudad de Málaga [8].

63 CAMACHO MARTíNEZ, R.: "Los órganos de la Catedral de Málaga. Análisis estilístico y documental", Cuadernos de Arte de la Universidad de Granada n 16, Granada, 1984, págs. 265-281. 


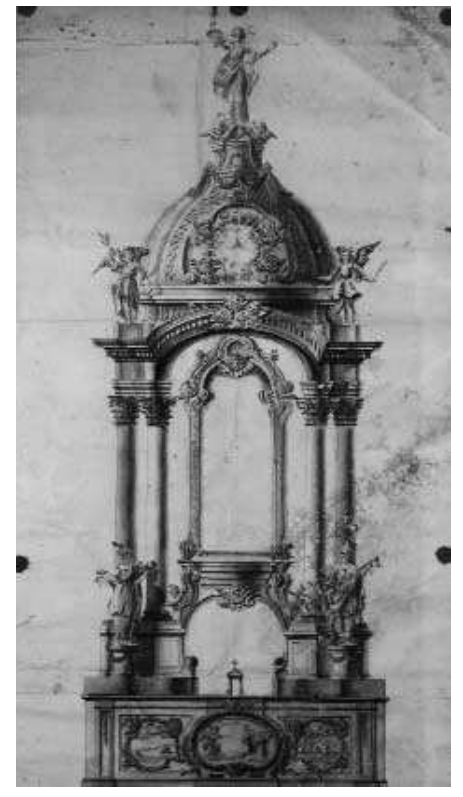

9. José MaRtín DE ALDEHUELA. Alzado del proyecto de Tabernáculo. 1796 .
A la derecha se dibuja la proyección de la cubierta, marcándose alrededor de las columnas el vuelo de los capiteles y su integración en una airosa forma curva que sujeta la bóveda; ésta se cala con vanos trilobulados entre las columnas, arrancando de las que se disponen más al interior, otro cuerpo más sinuoso que conforma el cierre de la clave.

El alzado resulta muy esbelto. Centra el frontal de la mesa de altar un medallón oval arriñonado, (fórmula repetida por Aldehuela) con relieve de la Encarnación, advocación de la Catedral, entre otros dos relieves cuadrifoliados. Sobre él se alzan las cuatro parejas de columnas con hermosos capiteles corintios dorados, determinando planos oblicuos en una inestable diagonal y, entre sus ángulos, las del frente, alojan los pedestales para las referidas imágenes de Ciriaco y Paula que, ante los troncos sobre los que fueron lapidados y atados con los brazos abiertos, resultan un tanto declamatorios. Las columnas sostienen entablamento de cornisa denticulada que forma el arco rebajado del frente, dejando un fuerte estrangulamiento en las enjutas, decoradas con escotas y, para ser apoyo de la bóveda, se proyecta hacia adelante rematando en la clave con querubines; sobre aquellas, ángeles con las palmas y varas de martirio flanquean el trasdós de la pequeña cúpula, una estructura horadada, que podría inspirarse en la que utilizó Ventura Rodríguez en la capilla de la Virgen del Pilar de Zaragoza. Sobre el anillo apoyan cuatro grandes nervios doblados, cuyo ritmo de colocación lo marca la disposición de las columnas, ligeramente enrollados en la base para recercar a unos óculos de diseño curvo irregular, con querubines, y permiten ver en el interior una gloria con el triángulo divino. En la clave, paños colgantes y querubines rodean un pedestal que apoya una imagen triunfante de la Fe sobre escabel nebuloso jalonado por serafines [9].

En su interior se dispone un baldaquino dorado que es doble. El espacio que hay sobre el altar, que acoge un pequeño Sagrario, se conforma mediante líneas de suaves curvas que arrancan de las basas de las columnas del tabernáculo rematado en la clave de los arcos por un querubín. De las mismas basas surgen unas potentes ménsulas que sostienen una estructura más aérea y rica, dorada, de signo marcadamente romano por su etéreo impacto visual y prestancia escenográfica, entrela- 
zándose los nervios para formar una cubierta abovedada, que promete transparencias, y sobre la cual los querubines ejercen una presencia simbólica, formando un airoso expositor para el Santísimo Sacramento. Aldehuela secunda, de este modo, la moda del barroco clasicista de influencia italiana -por lo demás, presente en los dibujos de arquitectos y escultores del período como Ventura Rodríguez, Juan Pedro Arnal, Juan Antonio Munar, Juan Adán, Alfonso Giraldo Vergaz o el mismo Silvestre Pérez- de recuperar el motivo del querubín para remedar, acorde al dictado dieciochesco, la impronta del propiciatorio del Arca de la Alianza, desde donde se revelaba la Shekinah o manifestación de Yahvé al Sumo Sacerdote de Israel. Es más, la voluntad clasicista de depurar los exuberantes repertorios ornamentales del barroco castizo reconocen en la presencia frecuente del querubín en estos diseños un refuerzo del propio trasfondo conceptual de estos seres fabulosos,

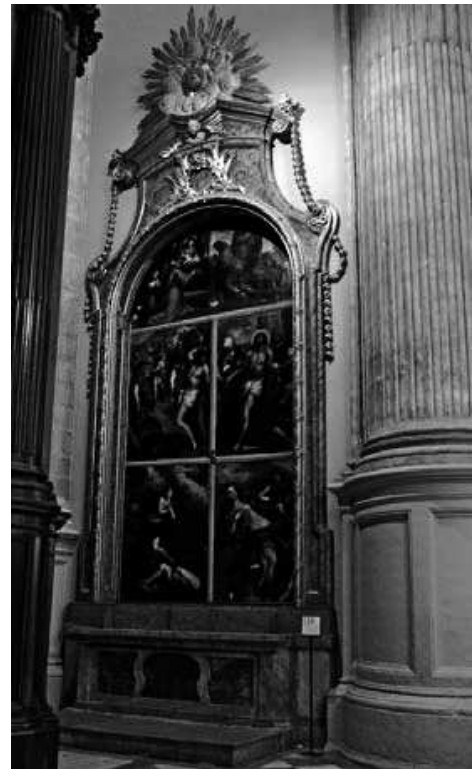

10. Catedral de Málaga. Retablo de San Sebastián.

extraordinariamente próximos al conocimiento de la Divinidad y receptores supremos de la luz del entendimiento y de la razón, pues, como apunta Santo Tomás de Aquino, cherubim interpretatur plenitudo scientiae 64.

Ponz criticó también este tabernáculo, juicio que contrasta con el elogio que dedica a otro pequeño, pero elegantísimo, retablo de la Catedral diseñado por Aldehuela en 1782, el de San Sebastián, colocado junto al cancel del lado del Evangelio, que responde al mismo estilo65. Por la necesidad de adaptarse a su ingrata situación y también por el presupuesto, como obra de promoción particular del canónigo Juan Altamirano, Aldehuela diseñó el retablo con un sentido planista, sin pretensiones, concebido como un marco de medio punto con gruesa moldura de bocelón con estilizadas palmetas para los lienzos que encierra, fechados en 1596, con formas adecuadas y precisas en oro y estuco blanco que resaltan sobre el veteado de los mármoles fingidos, empleándose tan sólo en la labor decorativa del remate superior [10].

64 RAMÍREZ DOMíNGUEZ, J.A.: Edificios y Sueños (Ensayos sobre arquitectura y utopía), Universidad de Salamanca-Colegio de Arquitectos y Universidad de Málaga, 1983, págs. 251-253.

65 PONZ, A.: Op cit. pág. 183. CAMACHO MARTÍNEZ, R.: "Un arquitecto turolense en Málaga: José Martín de Aldehuela”. Primer Coloquio de Arte Aragonés. Teruel 1978. Textos págs. 84-87. 
artículos Rosario Camacho Martínez y Juan Antonio Sánchez López

En este diseño de tabernáculo que presentamos, generado con la tridimensionalidad que le imprimen espacios y volúmenes de gran complejidad, a los que se une una finísima decoración, Aldehuela demuestra que, aunque en esos años estaba más volcado en empresas de ingeniería, y ha realizado obras que tienden a un mayor clasicismo, no había olvidado los diseños de ornato rococó y las técnicas de carpintería y de hacer el estuco, que aquí se funden, para crear una pieza verdaderamente exquisita, cuyos elementos se disponen acordes para crear un espacio de santificación y exaltación del Santísimo Sacramento. A propósito de ello, cabría intuir, por su parte, una sugestiva 'regresión' ¿reivindicativa? a aquellos momentos anteriores de su carrera donde la libertad de formas y el ingenio en la composición le permitían soñar, sin trabas, normas, ni cánones, con el Reino de Utopía. 